\title{
A Rhizobium leguminosarum Biovar trifolii Locus Not Localized on the Sym Plasmid Hinders Effective Nodulation on Plants of the Pea Cross-Inoculation Group
}

\author{
Henk P. Roest, Ine H. M. Mulders, Herman P. Spaink, Carel A. Wijffelman, and Ben J. J. Lugtenberg \\ Leiden University, Institute of Molecular Plant Sciences, Clusius Laboratory, Wassenaarseweg 64, 2333 AL \\ Leiden, Netherlands \\ Received 17 March 1997. Accepted 4 June 1997.
}

\begin{abstract}
Introduction of the Sym plasmid pRL1JI into the cured Rhizobium leguminosarum bv. trifolii strain RCR5 resulted in a strain, designated RBL5523, that was expected to nodulate plants of the pea cross-inoculation group. However, effective nodulation occurred only on Vicia sativa plants, not on $V$. hirsuta or Pisum sativum. After random Tn5 mutagenesis, a derivative of RBL5523 was isolated that effectively nodulated and fixed nitrogen on $P$. sativum and $V$. hirsuta. Characterization of the mutant, RBL5787, indicated the cell surface components, extracellular polysaccharides, lipopolysaccharides, and outer membrane proteins, as well as the pattern of Nod metabolites, were indistinguishable from those of the parental strain. To obtain an indication of the function of the mutated locus, the flanking regions were sequenced and used to perform searches in protein and nonredundant nucleotide databases. No significant similarity or homology with any known sequence was detected.
\end{abstract}

Additional keywords: host specificity, $\mathrm{N}_{2}$ fixation, $R$. leguminosarum bv. viciae, transposon.

Formation of nitrogen-fixing root nodules involves a succession of signal exchanges between the host plant and symbiont. Discrepancies in this molecular communication result in impaired symbiosis. As a consequence, the number of host plant species that can be nodulated by one genus or biovar is often limited and usually is determined by the type of Sym plasmid present (for a review, see Long 1989). As was shown by van Brussel et al. (1982), the chromosomal background also plays an important role in effective symbiosis. In the current work, we describe the isolation of a Rhizobium legu-

Corresponding author: H. P. Spaink; Phone: +31-715275055; Fax: +31-715275088; E-mail: Spaink@ rulsfb.leidenuniv.nl

Present address of H. P. Roest: Department of Endocrinology and Reproduction, Erasmus University, P.O. Box 1738, 3000 DR Rotterdam, Netherlands.

Nucleotide and/or amino acid sequence data are to be found at GenBank, EMBL, or DDBJ as accession number X99107. minosarum strain mutated in a chromosomal locus that acts negatively on nodulation of Pisum sativum and Vicia hirsuta.

Strain RBL5523 is a derivative of $R$. leguminosarum bv. trifolii RCR5 in which the Sym plasmid is replaced by the $R$. leguminosarum bv. viciae Sym plasmid pRL1JI (Table 1) and, therefore, should effectively nodulate host plants of the pea cross-inoculation group. This strain, indeed, effectively nodulated $V$. sativa plants but could nodulate $P$. sativum only to the extent that it formed small white bumps on the root system of these hosts. To investigate the genetic basis of this discrepancy, RBL5523 bacteria were mutagenized randomly with Tn5 (Beringer et al. 1978). Approximately 10,000 kanamycin-resistant $\left(\mathrm{Km}^{\mathrm{r}}\right)$ colonies were pooled and tested for their ability to form effective nodules on $P$. sativum plants. Four weeks after inoculation with the mixture of Tn5-marked RBL5523 bacteria, the root systems of 28 P. sativum plants were checked for the presence of effective nodules. Seventeen pink nodules, indicative of nitrogen-fixing activity, were found among many small, white bumps (Fig. 1). The effective nodules were excised from the roots, surface-sterilized, and their bacteria were reisolated. Bacteria from single colonies appeared to be rifampicin and spectinomycin $(\mathrm{Spc})$ resistant, ruling out the possibility of contamination. All colonies were also $\mathrm{Km}^{\mathrm{r}}$. This indicated that all of the colonies were $\operatorname{Tn} 5$ mutants originating from strain RBL5523 and that no mixed occupation of these nodules by mutated and parental bacteria had occurred. Three individual colonies of each of the seventeen reisolates were maintained on agar plates without antibiotics and tested for their nodulation ability on $P$. sativum plants. All plants contained normal, effective nodules indicative of stable integration of the transposon.

To determine the number of different mutants, genomic DNA from a single colony of each of the 17 reisolates was obtained, digested with either EcoRI or HindIII, and probed with Tn5 DNA for Southern analysis. All mutants appeared to have received only one copy of Tn5, and two different types of mutants were identified. Type A had the transposon inserted in an EcoRI fragment of approximately $4.6 \mathrm{~kb}$ (14 mutants of 17 tested); type B had the transposon integrated in an EcoRI fragment of approximately $1.5 \mathrm{~kb}$ (3 mutants of 17 tested). To 
test the correlation between effective nodulation and insertion of Tn5, a phage lysate (RL38JI; Buchanan-Wollaston 1979) was made of all 17 mutants. Each lysate was separately transduced into the parent strain, RBL5523, and $\mathrm{Km}^{\mathrm{r}}$ bacteria were tested for their nodulation phenotype on $P$. sativum. The results showed that only transductants originating from the type A mutant lysates retained the effective nodulation phenotype. Transduction of type B mutant lysates resulted in a phenotype similar to that of parental strain RBL5523. One of the 14 type A mutant strains, designated RBL5787, was selected for further characterization.

A substantial difference in $\mathrm{N}_{2}$-fixation levels can occur between Rhizobium strains that belong to the same cross-inoculation group (van Brussel et al. 1982). We assayed the acetylene reduction of strains RBL5787 and RBL5523 as a measure for their $\mathrm{N}_{2}$-fixing ability (Hardy et al. 1968) and compared the levels to that of wild-type R. leguminosarum bv. viciae strain 248 on three different host plants. The mutation clearly increased the effectiveness of strain RBL5787 on $V$. hirsuta and P. sativum compared to strain RBL5523. Moreover, the levels on $P$. sativum were even higher with strain RBL5787 than with strain 248 (Fig. 2). $\mathrm{N}_{2}$-fixation levels on $V$. sativa were similar between strains RBL5787 and RBL5523, but both exceeded the levels obtained with strain 248 . This confirmed the notion that the bacterial genetic background and the host plant codetermine $\mathrm{N}_{2}$-fixation levels.

Transconjugation with strain RBL5506 as the recipient strain demonstrated that no cotransfer of the $\mathrm{Spc}^{\mathrm{r}}$ and $\mathrm{Km}^{\mathrm{r}}$ markers had occurred, indicating that the gene mutated in RBL5787 was not located on pRL1JI. The pattern of Nod metabolites, secreted by RBL5523 and RBL5787 and analyzed on thinlayer chromatography plates (Spaink et al. 1992), was indistinguishable and supported the idea that the nod genes were not affected by the Tn5 mutation (data not shown).

Beyond the phase of nodule initiation, a stage in the interaction between $P$. sativum and RBL5523 that apparently is not disturbed, further bacterium-plant recognition via surface-surface interactions are probably important in the establishment of fully developed and functional nodules (Gray et al. 1992).
Mutated strains with lesions in their extracellular polysaccharides (EPS) can form empty ineffective nodules on the proper, indeterminate-nodulating host plant (Yang et al. 1992), and mutants with aberrant lipopolysaccharides (LPS) can trigger a host plant defense reaction (Perotto et al. 1994). The mutant strain RBL5787 was compared to the parental strain for (i) colony morphology on $\mathrm{B}^{-}$medium (van Brussel et al. 1977) as a marker for EPS alterations and (ii) the LPS and outer membrane protein profiles by sodium dodecyl sulfate-polyacrylamide gel electrophoresis (de Maagd et al. 1988). No differences in one or more of these components were observed between strains RBL5523 and RBL5787 (data not shown).

Therefore, we decided to clone the locus responsible for the impaired effectiveness of $P$. sativum root nodules after inoculation with RBL5523. Genomic DNA from strain RBL5787 was isolated, BamHI digested, ligated in pIC20H (Marsh et al. 1984), and transformed to Escherichia coli (Maniatis et al. 1982). Nine $\mathrm{Km}^{\mathrm{r}}$ transformants were obtained that all contained an identical insert of approximately $11 \mathrm{~kb}$ (Fig. 3). A HpaI-EcoRI fragment $(2.95 \mathrm{~kb})$ of this plasmid (pMP3701) was isolated and used to screen a cosmid library of LPR5020 (Roest et al. 1995). Four different cosmids were obtained that, unfortunately, had the Tn5 insertion in RBL5787 located very closely to the border of the insert. Restriction patterns of the two largest cosmids, pMP3716 and pMP3717, are shown in Figure 3. The nucleotide sequence of the regions directly flanking the position of the Tn5 insertion (Fig. 3, hatched bar) was determined. We used this 475-nt sequence to perform BLAST (basic local alignment search tool searches) (Altschul et al. 1990) in protein and nonredundant nucleotide databases, but no significant homology $(P(N)<0.01)$ with any submitted protein or nucleotide sequence was observed (Karlin and Altschul 1990).

Genes that act in a host range-limiting way, either located on the Sym plasmid or other parts of the genome (Meinhardt et al. 1993; Lewis-Henderson and Djordjevic 1991), have been described before. These genes, however, play a role in cultivar specificity. This study is, to our knowledge, the first one to describe a mutation that improves the effectiveness of nodulation at the genus rather than the cultivar level. It is tempting

Table 1. Bacterial strains and plasmids and their characteristics

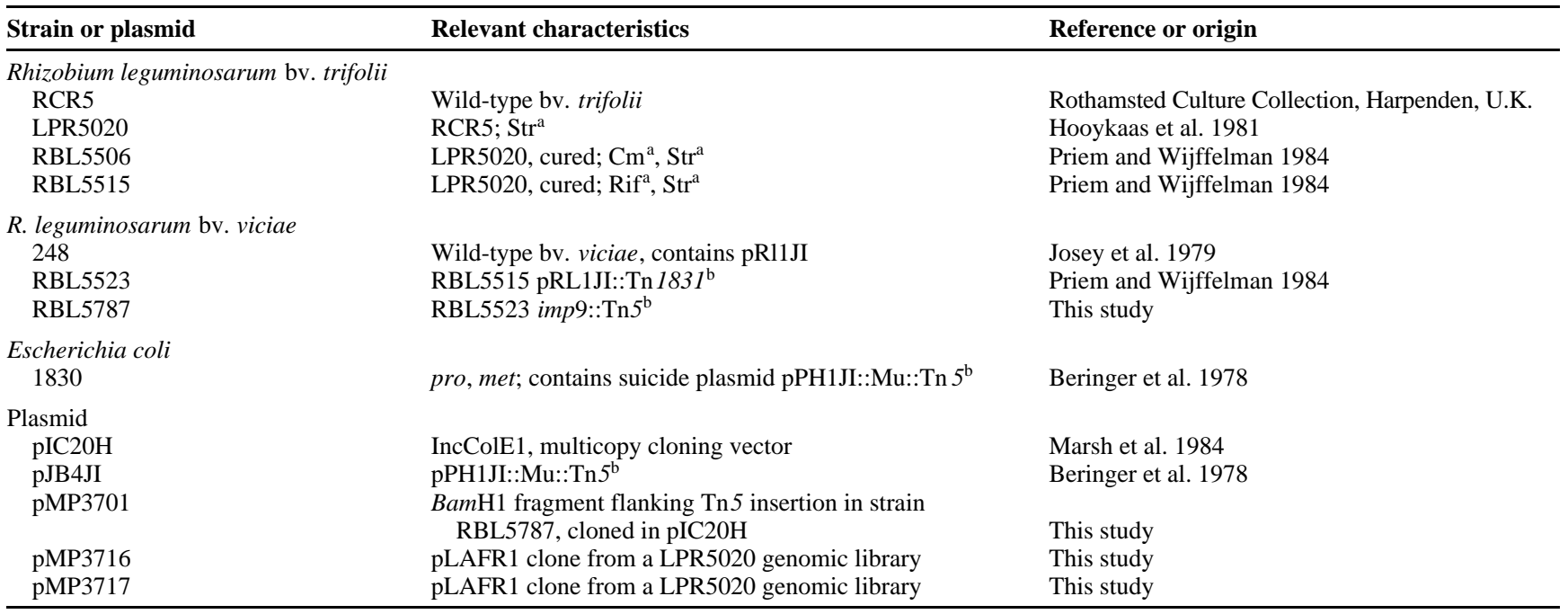

a Antibiotic resistance: $\mathrm{Str}=$ streptomycin; $\mathrm{Cm}=$ chloramphenicol; and Rif = rifampicin .

${ }^{\mathrm{b}} \operatorname{Tn} 5=$ kanamycin resistance and $\operatorname{Tn} 1831=$ spectinomycin resistance. 


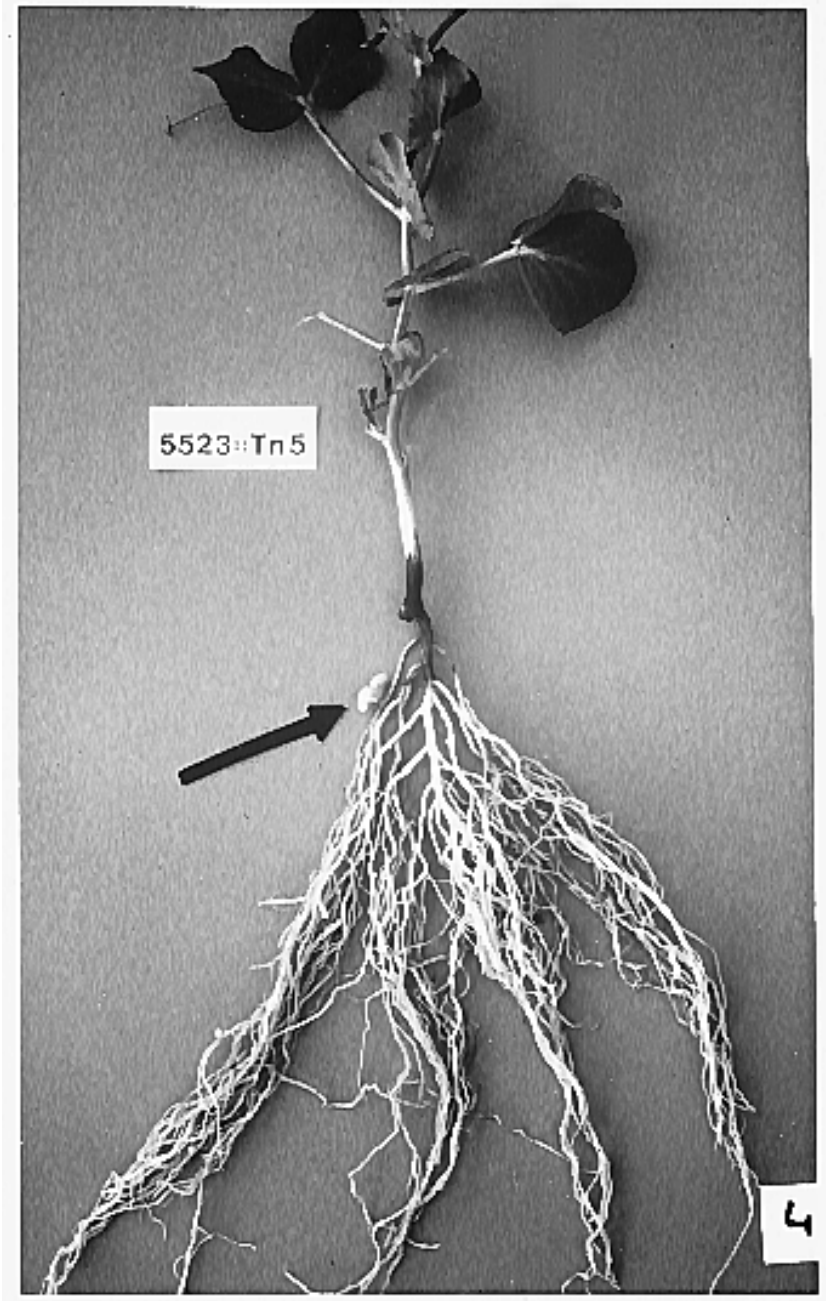

Fig. 1. Root system of a pea plant 4 weeks after inoculation with a Tn5mutagenized library of Rhizobium leguminosarum bv. viciae RBL5523. The arrow points to the only large, pink nodule present on the roots of this plant.

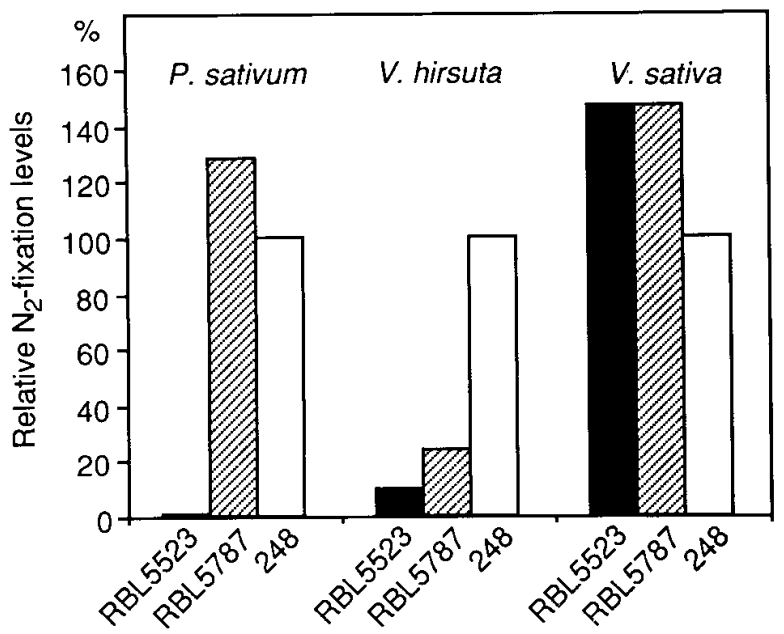

Fig. 2. Levels of acetylene reduction of Rhizobium leguminosarum bv. trifolii RBL5523 and RBL5787 compared with $R$. leguminosarum bv. viciae 248 . The levels of acetylene reduction by strain 248 were set at $100 \%$. Assays were performed on Pisum sativum, Vicia hirsuta, and V. sativa.

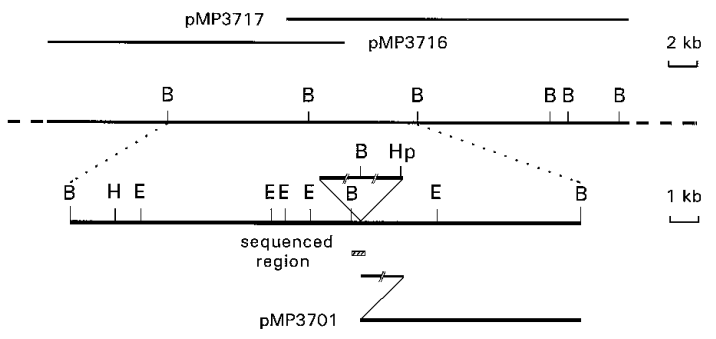

Fig. 3. Physical map of part of the chromosome of Rhizobium leguminosarum bv. trifolii RBL5523 investigated in this study. The position of the Tn5 insertion in R. leguminosarum bv. viciae RBL5787 is marked by the reversed triangle. The relevant fragments of plasmids pMP3701, pMP3716, and pMP3717 in relation to the map are indicated. The sequenced region is shown as a hatched bar. $\mathrm{B}=\operatorname{BamHI} ; \mathrm{E}=E c o \mathrm{RI} ; \mathrm{H}=$ HindIII; and $\mathrm{Hp}=H p a \mathrm{I}$. The length of the Tn5 arms is not drawn to scale, indicated by $/ /$.

to speculate that the gene mutated in strain RBL5787 is involved in synthesizing a bacterial compound that evokes a hypersensitive response on plants that do not function as natural hosts for these bacteria. The fact that nodule formation still occurs suggests that this compound does not play a role in nodulation but rather plays a role in subsequent stages of symbiosis.

\section{ACKNOWLEDGMENTS}

Our research was supported by a TMR grant from the European Community, Contract FMRX-CT96-0039 (DG12-MZLS).

\section{LITERATURE CITED}

Altschul, S. F., Gish, W., Miller, W., Myers, E. W., and Lipman, D. J. 1990. Basic local alignment search tool. J. Mol. Biol. 215:403-410.

Beringer, J. E., Beynon, J. L., Buchanon-Wollaston, A. V., and Johnston, A. W. B. 1978. Transfer of the drug-resistance transposon Tn5 to Rhizobium. Nature (Lond.) 276:633-634.

Buchanon-Wollaston, V. 1979. Generalized transduction in Rhizobium leguminosarum. J. Gen. Microbiol. 112:135-142.

de Maagd, R. A., van Rossum, C., and Lugtenberg, B. J. J. 1988 Recognition of individual strains of fast-growing Rhizobia by using profiles of membrane proteins and lipopolysaccharides. J. Bacteriol. 170:3782-3785.

Gray, J. X., de Maagd, R. A., Rolfe, B. G., Johnston, A. W. B., and Lugtenberg, B. J. J. 1992. The role of the Rhizobium cell surface during symbiosis. Pages 357-376 in: Molecular Signals in Plant-Microbe Communications. D. P. S. Verma, ed. CRC Press Inc., Boca Raton, FL.

Hardy, R. W. F., Holsten, R. D., Jackson, E. K., and Burns, R. C. 1968. The acetylene-ethylene assay for nitrogen-fixation: Laboratory and field evaluation. Plant Physiol. 43:1185-1207.

Hooykaas, P. J. J., van Brussel, A. A. N., den Dulk-Ras, H., van Slogteren, G. M. S., and Schilperoort, R. A. 1981. Sym-plasmid of Rhizobium trifolii expressed in different Rhizobial species and Agrobacterium tumefaciens. Nature (Lond.) 291:351-353.

Josey, D. P., Beynon, J. L., Johnston, A. W. B., and Beringer, J. E. 1979. Strain identification in Rhizobium using intrinsic antibiotic resistance. J. Appl. Bacteriol. 46:343-350.

Karlin, S., and Altschul, S. F. 1990. Methods for assessing the statistical significance of molecular sequence features by using general scoring schemes. Proc. Natl. Acad. Sci. USA 87:2264-2268.

Lewis-Henderson, W. R., and Djordjevic, M. A. 1991. A cultivar-specific interaction between $R$. leguminosarum bv. trifolii and subterranean clover is controlled by nodM, other bacterial cultivar specificity genes, and a single recessive host gene. J. Bacteriol. 173:2791-2799.

Long, S. R. 1989. Rhizobium-legume nodulation: Life together in the underground. Cell 56:203-214.

Maniatis, T., Fritsch, E. F., and Sambrook, J. 1982. Molecular Cloning: A 
Laboratory Manual. Cold Spring Harbor Laboratory Press, Cold Spring Harbor, NY.

Marsh, J. L., Erfle, M., and Wykes, E. J. 1984. The PIC plasmid and phage vectors with versatile cloning sites for recombinant selection by insertional inactivation. Gene 32:481-485.

Meinhardt, L. W., Krishnan, H. B., Balatti, P. A., and Puepkke, S. G. 1993. Molecular cloning and characterization of a sym plasmid locus that regulates cultivar-specific nodulation of soybean by Rhizobium fredii USDA257. Mol. Microbiol. 9:17-29.

Perotto, S., Brewin, N. J., and Kannenberg, E. L. 1994. Cytological evidence for a host defense response that reduces cell and tissue invasion in pea nodules by lipopolysaccharide-defective mutants of Rhizobium leguminosarum strain 3841. Mol. Plant-Microbe Interact. 7:99-112.

Priem, W. J. E., and Wijffelman, C. A. 1984. Selection of strains cured of the Rhizobium leguminosarum Sym plasmid by using small bacteriocin. FEMS Microbiol. Lett. 25:247-251.

Roest, H. P., Bloemendaal, C.-J. P., Wijffelman, C. A., and Lugtenberg,
B. J. J. 1995. Isolation and characterization of ropA homologous genes from Rhizobium leguminosarum biovars viciae and trifolii. J. Bacteriol. 177:4985-4991.

Spaink, H. P., Aarts, A., Stacey, G., Bloemberg, G. V., Lugtenberg, B. J. J., and Kennedy, E. P. 1992. Detection and separation of Rhizobium and Bradyrhizobium Nod metabolites using thin-layer chromatography. Mol. Plant-Microbe Interact. 5:72-80.

van Brussel, A. A. N., Planqué, K., and Quispel, A. 1977. The wall of Rhizobium leguminosarum in bacteroid and free-living forms. J. Gen. Microbiol. 101:51-56.

van Brussel, A. A. N., Tak, T., Wetselaar, A., Pees, E., and Wijffelman, C. A. 1982. Small Leguminosae plants as test plants for nodulation of Rhizobium leguminosarum and other Rhizobia and Agrobacteria harbouring a leguminosarum Sym-plasmid. Plant Sci. Lett. 27:317-325.

Yang, C., Signer, E. R., and Hirsch, A. M. 1992. Nodules initiated by Rhizobium meliloti exopolysaccharide mutants lack a discrete, persistent nodule meristem. Plant Physiol. 98:143-151. 